\title{
MANFAAT MORINGA OLEIVERA.LAMK (KELOR) DALAM PERSPEKTIF AL QURAN
}

\section{Eny Yulianti}

Fakultas Sains dan Teknologi Universitas Islam Negeri Maulana Malik Ibrahim, Jalan Gajayana No.50. Telepon 0341-551354/0817273144, e-mail: enyuinmlg@yahoo.com

\section{Abstract}

Moringa oleivera. Lamk, known as Moringa, is native to north India but is now found throughout the tropics. Moringa is also known as horseradish tree, m. drumstick tree and mother's best friend. It grows fast and reaches up to The bark is grey and thick and looks like cork, peeling in patches. All Moringa food products have a very high nutritional value. Leaves rubbed against the temple can relieve headaches, to stop bleeding from a shallow cut, apply a poultice of fresh leaves. There is an anti-bacterial and anti-inflammatory effect when applied to wounds or insect bites. Extracts of leaves can be used against bacterial or fungal skin complaints. Leaf tea treats gastric ulcers and diarrhoea. Eating Moringa food products is good for those suffering from malnutrition due to the high protein and fibre content We can eat the leaves, especially young shoots, young pods, flowers, roots, and in some species even the bark. All of the parts of the tree can be used in a variety of quays. Moringa is full of nutrients and vitamins and is good in your food as well as in the food of your animals. Moringa helps to water purification and is a useful source of medicines. It provides lots of leafy material that is useful when using alley .cropping systems

Key words: moninga oleifera. lamk, nutrients and vitamins, water purification, natural medicines

Ulul Albab, Vol. 10, No. 1, 2009 


\section{Pendahuluan}

Tanaman kelor atau dalam bahasa latinnya dikenal sebagai Moringa oleivera.Lamk mempunyai manfaat yang sangat banyak. Moringa oleivera. Lamk atau Moringa saja merupakan tumbuhan asli India Utara, dan saat ini tersebar di seluruh wilayah Asia Tenggara, termasuk Indonesia. Tumbuhan ini juga banyak ditemukan di Mesir, Pakistan, Cuba, Jamaika, Nigeria, Sudan, dan Ethiophia (Mayer \& Stelz dalam Hidayat 2006). Beberapa negara menyebutnya sebagai drumstick (menjelaskan buahnya seperti tongkat kecil) dan horseradish tree (Hidayat, 2006: 13).

Senegal secara besar-basaran berusaha mengatasi masalah gizi buruk yang melanda akibat kekeringan yang berkepanjangan. Negara di benua Afrika ini memanfaatkan tanaman kelor secara luas untuk mengatasi kekurangan gizi seperti gizi buruk, anemia, beri-beri, termasuk bayi yang mempunyai berat badan kurang untuk mengkonsumsi daun kelor, dan hasilnya nyata sehingga masalah gizi buruk dapat teratasi. Umumnya daun kelor digunakan dengan cara dikeringkan kemudian dibuat serbuk yang bisa ditambahkan pada makanan apa saja (Logu, 2005: 19).

Tumbuhan kelor di Indonesia sudah tidak asing lagi, apalagi dengan adanya pepatah "dunia tak selebar daun kelor". Masyarakat memanfaatkan kelor sebagai sayuran, tanaman pagar, a tau sekedar batas tanah. Banyak pula masyarakat yang menganggap tanaman kelor mempunyai kekuatan supra natural, yaitu untuk mengusir kekuatan jahat atau penawar ilmu hitam, bahkan sebagian masyarakat percaya orang yang semula berniat jahat akan mengurungkan niatnya jika melihat kelor yang tumbuh di pekarangan rumah tersebut. Masih banyak juga masyarakat yang menganggap tabu untuk mengkonsumsi daun kelor karena biasanya daun kelor bersama-sama : berbagai macam bunga lainnya, digunakan untuk memandikan jenazah, karena masyarakat percaya kelor dapat meluntirkan kekuatan magis yang. dimiliki si jenazah.

Allah menciptakan tumbuhan kelor kaya yang dengan manfaat itu semuanya diperuntukkan bagi kepentingan umat manusia. Tulisan 
singkat ini berisi penjelasan tentang kandungan nutrisi tumbuhan kelor, potensinya sebagai tanaman obat, sebagai koagulan limbah dan cara membudidayakannya. Penulis berharap tulisan ini dapat memberikan sedikit informasi tentang manfaat Moringa oleivera.Lamk (kelor), secara empiris dari hasil-hasil penelitian dan tinjauan manfaat diciptakan olehNya menurut perspektif al Quran.

Ayat-ayat al Quran banyak sekali yang memerintahkan manusia untuk selalu memikirkan hakikat penciptaan makluk-makluk Allah di alam semesta ini, dengan harapan manusia dapat mensyukuri nikmat Allah tersebut hingga menjadi insan ulul albab. Salah satu ayat al Quran yang menjelaskan tentang ulul albab adalah surah Ali Imron 190 berikut ini:

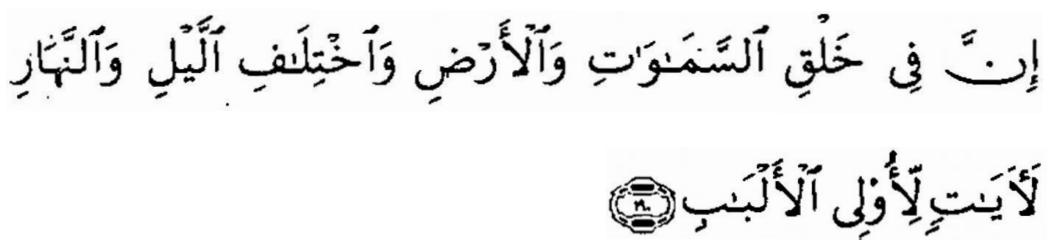

Sesungguhnya dalam penciptaan langit dan bumi, dan silih bergantinya malam dan siang terdapat tanda-tanda bagi orang-orang yang berakal, (QS. Ali lmron: 190).

Ayat tersebut menerangkan bahwa ulul albab adalah orang-orang yang (Wassil, 2001: 15):

1. Mengingat Allah dalam setiap keadaan

2. Memikirkan kejadian langit dan bumi, menguasai ilmu pengetahuan alam syahadat

3. Menyadari bahwa kejadian alam ini tidak sia-sia, ia selalu berusaha mendapatkan manfaatnya atau lebih tegas ia mengembangkan teknologi

4. Berdoa kepada Allah agar terlepas dari siksa neraka atau dengan perkataan lain ia sangat khawatir jangan-jangan usahanya berkesudahan dengan malapetaka

Kesadaran kita bahwa disa mping ayat-ayat al Quran berupa ungkapan kalimat-kalimat berisikan perkataan yang lazim disebut ayat kauliyah, ada juga ayat kauniyah yaitu ayat-ayat Allah yang berupa selain kalimat-kalimat- 
Nya, yakni alam jagat yang kita saksikan dengan pancaindra. Alam syahadat harus kita perhatikan sebagaimana yang diperintahkan dalam al Quran surah Ali Imron 190. Ilmu pengetahuan yang dikembangkan oleh umat manusia adalah ayat dari Allah juga. Kedua jenis ayat Allah ini tidak mungkin bertentangan. Satu sama lain saling menerangkan dan melengkapi. Tegasnya ilmu pengetahuan alam syahadat merupakan satu rujukan yang penting dalam mencari tafsir ayat-ayat al Quran.

\section{Moringa oleivera.Lamk}

Moringa oleivera.Lamk tumbuh dengan cepat hingga mampu mencapai $12 \mathrm{~m}$. Buahnya tebal dan abu-abu seperti gabus. Daun Moringa oleivera.Lamk berguguran dari bulan Desember hingga Januari dan akan tumbuh kembali mulai Februari hingga Maret. Moringa oleivera.Lamk berbunga sejak berumur 8 bulan dan rata-rata pada bulan Januari hingga Maret. Buah menjadi masak dari April ke Juni dan buahnya berbentuk kelopak polong berbentuk segi tiga dengan panjang 30 hingga $50 \mathrm{~cm}$. Kelopak berisi biji berwarna hitam dan bersayap yang mengandung minyak (www. gardenorganic.org.).

Moringa oleivera.Lamk mempunyai suatu akar tunggal yang dalam dan sedikit akar cabang sehingga Moringa oleivera.Lamk tidak bersaing untuk mendapatkan bahan makanannya, bahkan Moringa oleivera.Lamk akan memberikan pupuk pada tanaman di sekitarnya, karena daun-daunnya yang jatuh mengandung nitrogen yang cukup tinggi sangat dibutuhkan oleh tanaman. Kelor dapat tumbuh dengan cepat tetapi tidak menjadi sangat teduh karena struktur daun-daunnya yang kecil-kecil. Kelor juga juga sangat baik untuk memperbaiki tanah-tanah yang kritis. Kenyataan ini sama seperti yang telah diungkapkan dalam al Quran:

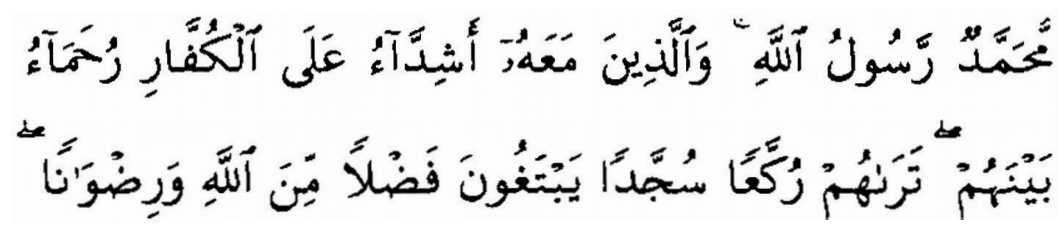

Ulul Albab, Vol. 10, No. 1, 2009 


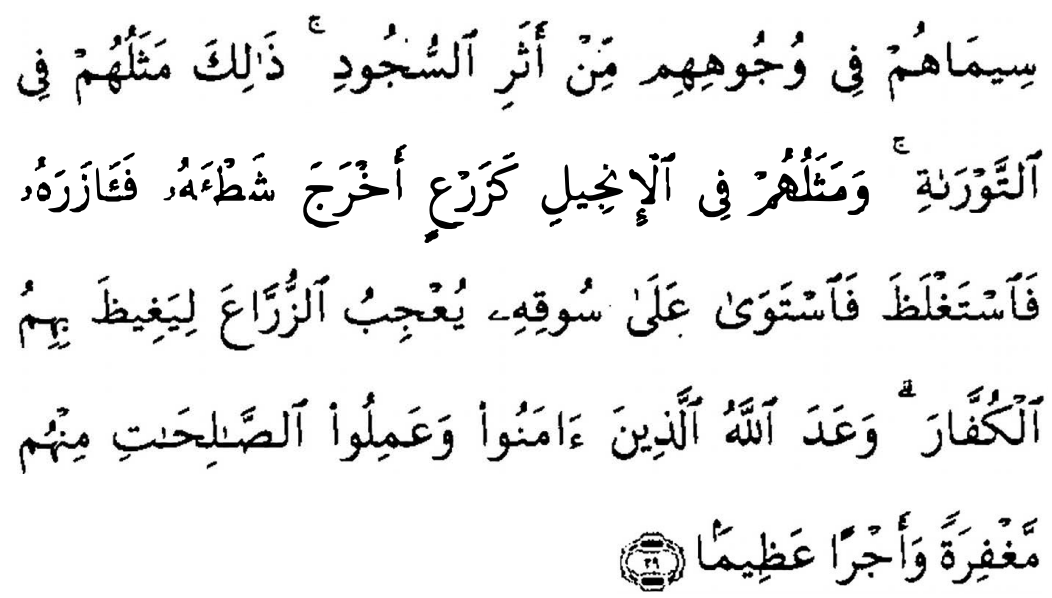

Muhammad itu adalah utusan. Allah dan orang-orang yang bersama dengan dia adalah keras terhadap orang-orang kafir, tetapi berkasih sayang sesama mereka. Kamu lihat mereka ruku' dan sujud mencari karunia Allah dan keridhaan-Nya, tanda-tanda mereka tampak pada muka mereka dari bekas sujud. Demikianlah sifat-sifat mereka dalam taurat dan sifat-sifat mereka dalam injil, yaitu seperti tanaman yang mengeluarkan tunasnya maka tunas itu menjadikan tanaman itu kuat lalu menjadi besarlah dia dan tegak lurus di atas pokoknya; tanaman itu menyenangkan hati penanam- penanamnya karena Allah hendak menjengkelkan hati orang-orang kafir (dengan kekuatan orang-orang mu'min). Allah menjanjikan kepada orang- orang yang berinan dan mengerjakan amal yang salch di antara mereka ampunan dan pahala yang besar (QS. al Fath: 48).

Kelor (Moringa oleivera.Lamk) termasuk jenis tumbuhan perdu yang dapat memiliki ketinggian batang $7-12$ meter. Pohon kelor tidak terlalu besar, batang kayunya getas (mudah patah) dan cabangnya jarang tetapi mempunyai akar yang kuat. Daunnya berbentuk bulat telur dengan ukuran kecil-kecil bersusun majemuk clalam satu tangkai. Bunganya berwarna putih kekuningkuningan dan tudung pelepah bunganya berwarna hijau. Bunga kelor keluar sepanjang tahun dengan aroma bau semerbak (www.gardenorganic. org.). Allah telah menciptakan bentuk tumbuhan kelor dengan begitu sempurnanya, seperti yang disebutkan dalam al Quran:

Ulul Albab, Vol. 10, No. 1, 2009 


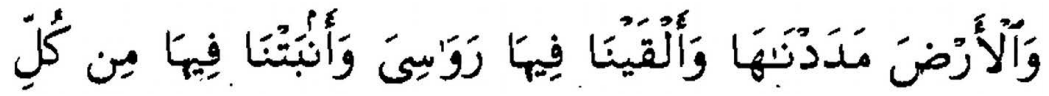

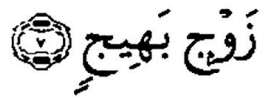

Dan Kami hamparkan bumi itu dan Kami letakkan padanya gunung.gunung yang kokoh dan Kami tumbuhkan padanya segala macam tanaman yang indah dipandang mata (QS. Qaaf: 50).

Berikut ini gambar daun dan bunga kelor:
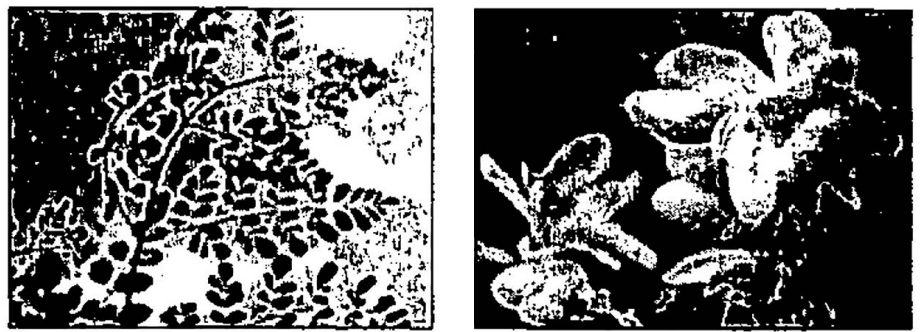

Gambar 1. Daun dan Bunga Kelor (www.treesforlife.org)

Buah kelor berbentuk segitiga memanjang yang disebut klentang (jawa), berikut adalah gambar polong buah kelor (Moringa oleivera.Lamk):

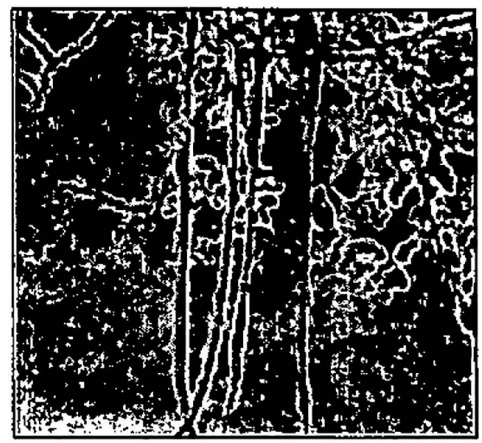

Gambar 2. Buah Kelor (www.treesforlife.org)

Semua komponen dari pohon dapat dimanfaatkan, mulai daun, bunga, buah, batang pohon bahkan akarnya.. Beberapa manfaat Moringa oleivera.Lamk secara umum sebagai berikur (www.gardenorganic.org): 
1. Sumber makanan yang sangat bergizi

2. Makanan ternak

3. Pengkoagulan pada penjernihan air

4. Obat

5. Pupuk

6. Pestisida alami

7. Kayu bakar dan lain-lain

Secara garis besar manfaat Moringa oleivera.Lamk dapat dibedakan menjadi : Moringa oleivera.Lamk banyak mengandung zat yang bergizi dan vitamin. Moringa oleivera.Lamk bermanfaat sebagai tanaman obat dan juga bermanfaat dalam penjernihan air.

\section{Kandungan Nutrisi Tumbuhan Kelor}

Semua bagian tanaman Moringa oleivera.Lamk merupakan sumber makanan yang mempunyai nilai gizi sangat tinggi. Kita dapat menggunakan daun-daun, tunasmuda, kelopak; polong muda, bunga maupun akar. Daundaunnya mengandung lemak dan karbohidrat dalam jumlah kecil, tetapi kaya akan mineral dan vitamin B. Dari seluruh bagian tanaman, daun adalah bagian yang paling banyak digunakan. Agar lebih banyak daun yang tumbuh, disarankan untuk memangkas beberapa bagian batangnya, hingga bisa bersemi kembali. Umumnya yang digunakan adalah daun-daun yang masih muda karena jika yang sudah tua, tidak akan empuk, meskipun dipanaskan lebih lama. Daunnya dapat dimasak dengan cara yang sama seperti memasak sayur bayam. Serbuk daun dapat dibuat dengan cara mengeringkan daun dengan oven kemudian menumbuknya hingga halus, selanjutnya serbuk ini dapat ditambahkan dalam beberapa makanan apa saja yang diinginkan (www.gardenorganic.org.).

Biji kelor dapat dimanfaatkan saat masih muda maupun tua. Biji dimasak dengan cara dikeluarkan dari polongnya bersamaan dengan bagian sayapnya, untuk memisahkan kulit luarnya bisa dengan cara dipanaskan dalam air mendidih, cara ini akan memungkinkan kulit ari yang keras dan berasa pahit ikut lepas, selanjutnya direndam dalam air dingin untuk

Ulul Albab, Vol. 10, No. 1, 2009 
memisahkannya. Biji tanpa kulit ari ini dapat dimasak, seperti memasak kacang hijau. Biji tua yang ditandai dengan warna polong yang berwarna coklat, mengandung $35 \%$ minyak yang bisa dipisahkan dengan cara ekstraksi maupun pres, keunggulan minyak biji kelor tidak mudah menjadi tengik, dan jika digunakan sebagai bahan bakar, tidak menghasilkan asap yang dapat mencemari lingkungan. Minyak biji kelor memilki mutu gizi dan fungsional tinggi dan memiliki nilai jual (harga) yang tinggi pula. Minyak kelor sangat baik untuk minyak goreng maupun sebagai bahan dasar pembuatan sabun. Minyak biji kelor dapat pula digunakan sebagai bahan kerosin atau minyak untuk lampu teplok pengganti penerangan di daerah yang belum ada listrik. Saat tingginya belum mencapai $60 \mathrm{~cm}$, akar pohon Moringa oleivera.Lamk dapat dimanfaatkan sebagai obat dengan dosis (www.gardenorganic.org.).

Nilai Nutrisi polong (buah), daun, dan serbuk daun per 100 gram tanaman yang dapat dikonsumsi (Logu, 2005: 3)

\begin{tabular}{|c|c|c|c|c|}
\hline No: & Komrosisi & Polong & Daun & Serbuk \\
\hline 1. & Kelembaban & 86,9 & 75 & 7,5 \\
\hline 2. & Kalori (g) & 26.0 & 92 & 205 \\
\hline 3. & Protein $(\mathrm{g})$ & 2,5 & 6,7 & 27,1 \\
\hline 4. & Lemak (g) & 0,1 & 1,7 & 2,3 \\
\hline 5. & Karbohidrat $(\mathrm{g})$ & 3,7 & 13,4 & 38.2 \\
\hline 6. & Serat (g) & 4,8 & 0,9 & 19,2 \\
\hline 7. & Mineral (g). & 12,0 & 2,3 & \\
\hline 8. & $\mathrm{Ca}$ (mg) & 30,0 & 440,0 & 2,003 \\
\hline 9 & $\mathrm{Mg}(\mathrm{mg})$ & 24 & 24 & 368 \\
\hline 10. & $\mathrm{P}$ (mg) & 110 & 70 & 204 \\
\hline 11. & $\mathrm{~K}(\mathrm{mg})$ & 1259 & 259 & 1324 \\
\hline 12. & $\mathrm{Cu}(\mathrm{mg})$ & 3,1 & 1,1 & 057 \\
\hline 13. & $\mathrm{Fe}(\mathrm{mg})$ & 5,3 & 7.0 & 28,2 \\
\hline 14. & $\mathrm{~S}(\mathrm{mg})$ & 137,0 & 137,0 & 870 \\
\hline 15. & Asam Oksalat (mg) & 10 & 101 & $1,6 \%$ \\
\hline 16. & Vit A/Beta Karoten (mg) & 0,11 & 6,8 & 16,3 \\
\hline 17. & Vit B /Cholin(mg). & 423 & 423 & $\cdot$ \\
\hline 18. & Vit Bl/Tiamin (mg) & 10,05 & 021 & 2,64 \\
\hline 19. & Vit B2/Ribloflavin (mg) & 0,07 & 0.05 & 20,5 \\
\hline 20. & Vit B3/Asam Nikotik (mg) & 0,2 & 0,8 & 8,2 \\
\hline
\end{tabular}




\begin{tabular}{|l|l|l|l|l|}
\hline 21. & Vit C / Asam Askorbik (mg) & 120 & 120 & 17,3 \\
\hline 22. & Vit E /Tokoferol Asetat (mg) & & & 113 \\
\hline 23. & Arginin & 3,6 & 6 & $1, \% 33$ \\
\hline 24. & Histidin & 1,1 & 2,1 & $0,61 \%$ \\
\hline 25. & Lisin & 1,5 & 4,3 & $1,32 \%$ \\
\hline 26. & Triftopan & 0,8 & 1,9 & $0,43 \%$ \\
\hline 27. & Fenilalanin & 4,3 & 6,4 & $1,49 \%$ \\
\hline 28. & Metionin & 1,4 & 2 & $0,35 \%$ \\
\hline 29. & Treonin & 3,9 & 4,9 & $1,1,9 \%$ \\
\hline 30. & Leusin & 6,5 & 9,3 & $1,95 \%$ \\
\hline 31. & Isoleusin & 4,4 & 6,3 & $0,83 \%$ \\
\hline 32. & Valin & 5,4 & 7,1 & $1,06 \%$ \\
\hline
\end{tabular}

Buah dan daun Moringa oleivera.Lamk dapat dijadikan sayuran. Nilai gizinya dapat dibandingkan terhadap bahan-bahan makanan lain, seperti pada bagan berikut ini (www.treesforlife.org):

Nilai Gizi daun Moringa oleivera. Lamk $=(7 \mathrm{x}$ Vit $C$ pada jeruk $)+(4 \mathrm{x}$ kalsium pada susu $)+(4 \times$ vit $A$ pada wortel $)+(3 \times$ potassium pada pisang $)$ $+(2 \times$ protein pada yogurt $)$.

\section{Kelor sebagai Tanaman Obat}

Di seluruh dunia, tiap-tiap bagian dari tumbuhan kelor telah digunakan secara efektif untuk melawan berbagai macam penyakit, diantaranya:

1. Daun

Daun kelor selain mengandung protein dan serat yang tinggi sehingga sangat baik untuk mencukupi gizi juga berkasiat sebagai obat. Ekstrak etanol daun kelor daun kelor dengan dosis 4,5 dan 13,5 (g/ kgBB) menunjukkan efek analgetik masing-masing sebesar $(59,762,49 \%$ dan $65,812,24 \%)$ pada mencit betina galur Swiss. Daun-Daun kelor dapat menyembuhkan sakit kepala (Inayah, 2006).

Tumbukan daun kelor segar bermanfaat untuk menghentikan . pendarahan dari luka, dengan cara ditempelkan pada luka tersebut. Tumbukan daun ini juga berfungsi sebagai anti-bacterial dan antiinflammatori atau radang pada luka bekas gigitan serangga atau hewan.

Ulul Albab, Vol. 10, No. 1, 2009 
Ekstraknya digunakan menyembuhkan sakit kulit yang disebabkan jamur dan bakteri. Teh daun Moringa oleivera .Lamk dapat digunakan untuk menyembuhkan keluhan penyakit maag dan diare. Remasan daun kelor dapar dimanfaatkan sebagai parem penutup bekas gigitan anjing dan dapat dibalurkan pada payudara ibu yang menyusui untuk menahan mengucurnya ASI yang berlebihan (Winarno, 2003: 1).

\section{Bunga}

Jus bunga kelor dapat meningkatkan kualitas dan kuantitas ASI, selain itu Jus bunga kelor mempunyai efek diuretika, atau melancarkan air seni.

3. Polong

Polong kelor selain mengandung protein dan serat yang tinggi, juga dapat berfungsi menyembuhkan permasalahan limpa dan hati dengan cara dimakan dalam keadaan segar.

4. Biji

Dapat digunakan sebagai anti bakteri dan anti-inflammatory penyakit radang sendi, encok, kram, penyakit seksual yang menular. Biji kelor disangrai, ditimbang dan dicampur dengan minyak kelapa dan dioleskan pada daerah yang sakit. Minyak biji kelor bisa juga dimanfaatkan. Minyak biji kelor juga dapat memperlancar air seni. Biji juga digunakan sebagai penenang untuk mengurangi gejala penyakit epilepsi (www.gardenorganic.org.).

\section{Akar, dan Getah}

Akar pohon kelor mempunyai kandungan yang sama seperti telah diuraikan di atas, tetapi pada akar ini lebih banyak konsentrasinya. Oleh karena itu akat ini lebih diutamakan sebagai obat (www.garderiorganic.org.).

Akar kelor sering digunakan sebagai bumbu campuran untuk merangsang nafsu makan, tetapi bila terlalu banyak dikonsumsi ibu yang sedang mengandung dapat menyebabkan keguguran. Tumbukan halus akar dapatdibuat bedak untuk tapel perut bayi yang baru lahir, sebagai pencegah iritasi kulit, dan sering digunakan sebagai obat penyakit kulit (jerawat) dan bisul, serta parem untuk bengkak-bengkak pada penyakit beri-beri dan bagi pengobatan kaki yang terasa pegal dan lemah (Winarno, 2003: 1).

Ulul Albab, Vol. 10, No. 1, 2009 


\section{Kelor sebagai Penjernih Air}

Allah menciptakan alam semesta untuk manusia agar manusia mau bersyukur. Bersyukur berarti memanfaatkan rahmat-rahmat Allah dengan selayaknya, karena segala pemberian Allah adalah penuh dengan Rahmat (Khoiroh, 2008: 16). Allah SWT berfirman dalam al Quran:

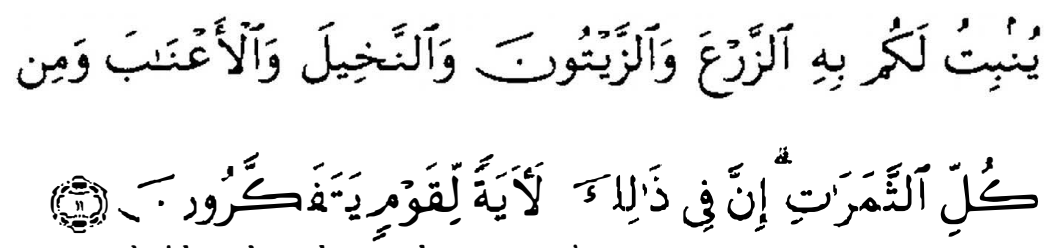

Dia menumbuhkan bagi kamu dengan air hujan itu tanam-tanaman; zaitun, korma, anggur dan segala macam buah-buahan. Sesungguhnya pada yang demikian itu benar-benar ada tanda (kekuasaan Allah) bagi kaum yang memikirkan (QS. an Nahl: 11).

Biji kelor selain digunakan untuk penjernih air juga dapar digunakan sebagai koagulan pengolah limbah. Semua tumbuhan yang diciptakan Allah sangat bermanfaat bagi terciptanya keseimbangan alam, salah satunya adalah kemampuan tumbuhan dalam menyerap $\mathrm{CO}$. Allah SWT berfirman dalam al Quran:

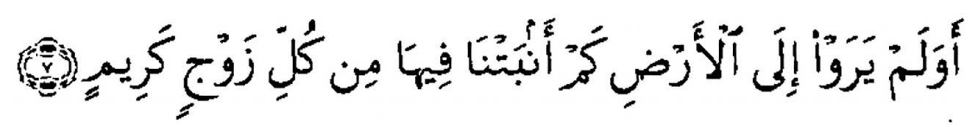

Dan apakah mereka tidak memperhatikan bumi, berapakah banyaknya Kami tumbuhkun di bumi itu pelbagai macam tumbuh-tumbuhan yang baik' (QS. asy Syri'ara: 26).

Biji kelor dapat berperan sebagai koagulan dengan hasil yang memuaskan. Bahkan biji tanamannya juga betkhasiat sebagai anti bakteri. Berdasarkan penelitian di Universitas Gadjah Mada, serbuk bijinya mampu membersihkan $90 \%$ dari total bakteri E.coli dalam satu liter ai waktu 20 menit. Biji kelor bisa dimanfaatkan sebagai koagulan sewaktu mengolah limbah cair pabrik tekstil. Hasilnya terjadi degradasi warna hingga $98 \%$, penurunan BOD $62 \%$, dan kandungan lumpur $70 \mathrm{ml}$ per liter. Biji Moringa oleivera. Lamk tidak beracun dan dapat diuraikan secara biologis dan ramah lingkungan. Penggunaan Moringa oleiveraLamk pada pengolahan lindi

Ulul Albab, Vol. 10, No. 1, 2009 
TPA (Tempat Pembuangan Akhir) Benowo dengan dosis $150 \mathrm{mg} / \mathrm{L}$ dapat mengurangi $90 \%$ kekeruhan, $83 \%$ TSS, $40 \%$ TDS, $19 \%$ COD dan 61,5 \% BOD (Dwiriyanti, 2005: 17). Biji kelor dapat digunakan sebagai penjernih air karena mengandung protein bermuatan positif yang berperan sebagai polielektrolit kationik (Hidayat, 2006: 133).

Biji Kelor (Moringa oleivera.Lamk) dengan dosis $500 \mathrm{mg} / \mathrm{lt}$ cukup efektif untuk digunakan sebagai bioflokulan logam berat $\mathrm{Hg}, \mathrm{Pb} \& \mathrm{Cr}$ limbah cair industri keramik. Penelitian ini juga mempelajari kemampuan biji kelor sebagai bioflokulan, yang mengandung protein bermuatan positif dengan senyawaan yang bermuatan sama (sampel paraquat atau 1,1'. Dimetil-4,4'bipiridilium Diklorida ) yang dikategorikan sebagai herbisida kationik) maupun berlawanan (sampel phospat yang anionik). Konsentrasi kelor sebesar 25000 ppm mampu mengendapkan secara signifikan larutan pestisida paraquat $4 \mathrm{ppm}$ dan konsentrasi kelor sebesar $2500 \mathrm{ppm}$ mampu mengendapkan larutan phospat 100 ppm (Yulianti, 2006: 57).

Biji Moringa oleivera.Lamk memiliki aktifitas flokulasi paling baik dibandingkan beberapa biji tumbuhan legum dan biji sereal lainnya. Serbuk biji kelor dapat dimanfaatkan sebagai bahan penurun kekeruhan air atau sebagai biokoagulan (Hidayat, 2006: 18).

Proses koagulasi pada pengolahan air meliputi tiga tahap, antara lain: penambahan dan pencampuran bahan koagulan, pemisahan antara partikel koloid atau disebut destabilisasi, dan benturan antar partikel yang sudah mengalami destabilisasi akibat gerakan molekul atau pengadukan. Gambar dari mekanisme koagulasi disajikan pada gambar berikut (Hasanah, 2008: 15): 
n)

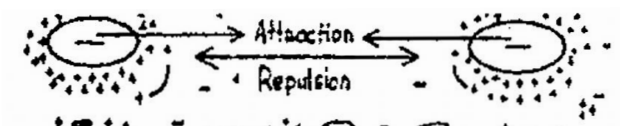

b)

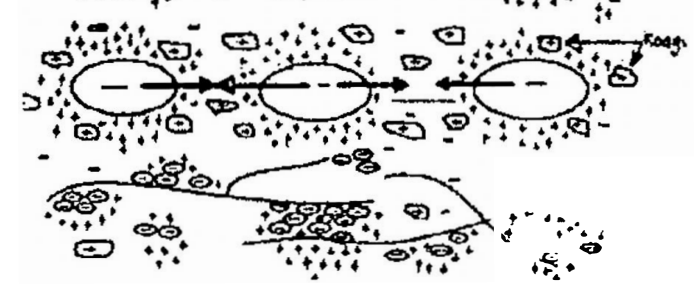

Gambar 3. Mekanisme Koagulasi a) gaya yang ditunjukkan oleh partikel koloid pada kondisi stabil. b) destabilisasi partikel koloid oleh penambahan koagulan.c) pembentukan flok-flok yang terikat membentuk benang panjang (Hammer, 2000 dalam Hasanah, 2008: 15).

Kelor dapat dimanfaatkan dalam pengolahan air bersih maupun pengolahan air limbah, caranya adalah (Esti dan Sahar, 2002) dan (www. gardenorganic.org.):

1. Kupas biji kelor dan bersihkan kulitnya.

2. Biji yang sudah bersih dibungkus dengan kain, kemudian ditumbuk sampai halus betul. Penumbukan yang kurang halus dapat menyebabkan kurang sempurnanya proses penggumpalan.

3. Campur tumbukkan biji kelor dengan air keruh dengan perbandingan 1 biji: 1 lt air keruh.

4. Campur tumbukkan biji kelor dengan sedikit air sampai berbentuk pasta.

5. Masukkan pasta biji kelor ke dalam air kemudian diaduk.

6. Aduklah secara cepat 30 detik, dengan kecepatan 55-60 putaran/ menit.

7. Kemudian aduk lagi secara berlahan dan beraturan selama 5 menit dengan kecepatan $15-20$ putaran/menit.

8. Setelah dilakukan pengadukan, air diendapkan selama 1-2 jam. Makin lama waktu pengendapan makin jernih air yang diperoleh.

9. Pisahkan air yang jernih dari endapan. Pemisahan harus dilakukan 
dengan hati-hati agar endapan tidak naik lagi.

10. Pada dasar bak pengendapan diberi kran yang dapat dibuka, sehingga endapan dapat dikeluarkan bersama-sama dengan air kotor.

Dosis yang dibutuhkan untuk mengolah air sebanyak 20 liter (1 jeriken), diperlukan jumlah bubuk biji kelor 2 gram atau kira-kira 2 sendok teh $(5 \mathrm{ml})$.

Kelor mempunyai zat aktif 4alfa-4-rhamnosyloxy-benzil-isothiocyanate. Zat aktif inilah yang berfungsi mengadsorpsi sekaligus menetralkan tegangan permukaan dari partikel-partikel air limbah. Biji kelor mengandung 35\% minyak berdasarkan berat kering. Hasil penelitian yang melaporkan bahwa bungkil ampas perasan minyak kelor masih banyak mengandung zat koagulan. Senyawa koagulan masih sangat berguna bagi proses pembersihan air dengan efektivitas sama bila digunakan biji utuhnya. Bungkil kelor dapat dikeringkan dan disimpan, merupakan produk samping industri minyak kelor yang berguna untuk menjernilikan air (Hidayat, 2006: 134).

\section{Pertumbuhan dan Perkembangan Kelor (Moringa oleivera.Lamk)}

Kelor (Moringa oleivera.Lamk) memerlukan daerah tumbuh dengan curah hujan $250 \mathrm{~mm}$ hingga $3000 \mathrm{~mm}$ per tahun. Saat musim kering, daundaunnya akan berguguran dan akan bersemi kembali saat musim hujan. Tanaman ini akan tumbuh dengan baik, pada daerah dengan ketinggian $600 \mathrm{~m}$ hingga $1000 \mathrm{~m}$ (www.treestighone.org.).

\section{a. Pertumbuhan dari Biji}

Sebelum ditanam, rendam biji Moringa oleivera.Lamk dengan air selama 1 hari dan ditanam dengan jarak $2 \mathrm{~cm}$ dengan kedalaman $1 \mathrm{~cm}$. Siram dengan sedikit air dan akan berkecambah dalam waktu 15 hari, ketika ketinggiannya mencapai $30 \mathrm{~cm}$, harus dipisahkan dengan jarak kurang lebih $10 \mathrm{~cm}$ dan saat sudah setinggi $60-90 \mathrm{~cm}$, semaian ini sudah dapat ditanam, dan harus hati-hati karena sangat mudah patah. Waktu yang dibutuhkan untuk proses tersebut kurang lebih 3 bulan.

b. Cara Stek

Stek dapat dilakukan pada cabang Moringa oleivera .Lamk yang

Ulul Albab, Vol. 10, No. 1, 2009 
selzat dengan kayu keras, dengan panjang $45 \mathrm{~cm}$ sampai $1,5 \mathrm{~m}$ dengan diameter kayu $\pm 10 \mathrm{~cm}$. Sebaiknya proses stek dilakukan pada musim hujan. Pemotongan kayu tidak boleh merusakkan bagian kulit, selanjutnya kayu tersebut diletakkan pada tempat terlindung selama 3 hari. Kayu dapat ditanam secara langsung di dalam lahan atau di dalam polybag yang berisi 3 bagian tanah dan 2 bagian pasir dengan kedalaman sepertiga bagian. Lahan harus lembab tetapi tidak kelebihan air. Potongan kayu yang ditanam di dalam polibag memerlukan waktu yang lama untuk mengembangkan akar dan baru bisa ditanam di lahan setelah 2 atau 3 bulan berikutnya.

c. Nilai Produksi

Setelah 3 tahun, satu pohon yang ditanam akan menghasilkan 300 sampai 400 polong setiap tahun dan satu pohon dewasa dapat menghasilkan sampai 1000 polong. Frekuensi pemotongan pada beberapa ujung cabang akan mempercepat pertumbuhan daun dan mempermudah proses pemanenan karena tingginya dapat dikendalikan.

\section{Simpulan}

Kita diperintahkan untuk selalu belajar dan terus belajar, menghayati maksud diciptakannya makhluk-makhluk Allah, mempelajari ayat-ayat Allah dalam alam syahadat atau alam jagad raya akan menyampaikan kita pada rasa iman padaNya Bahwa ayat-ayat dari alam syahadat menjadi obyek pengkajian para ulul-albaab diterangkan oleh ayat berikut:

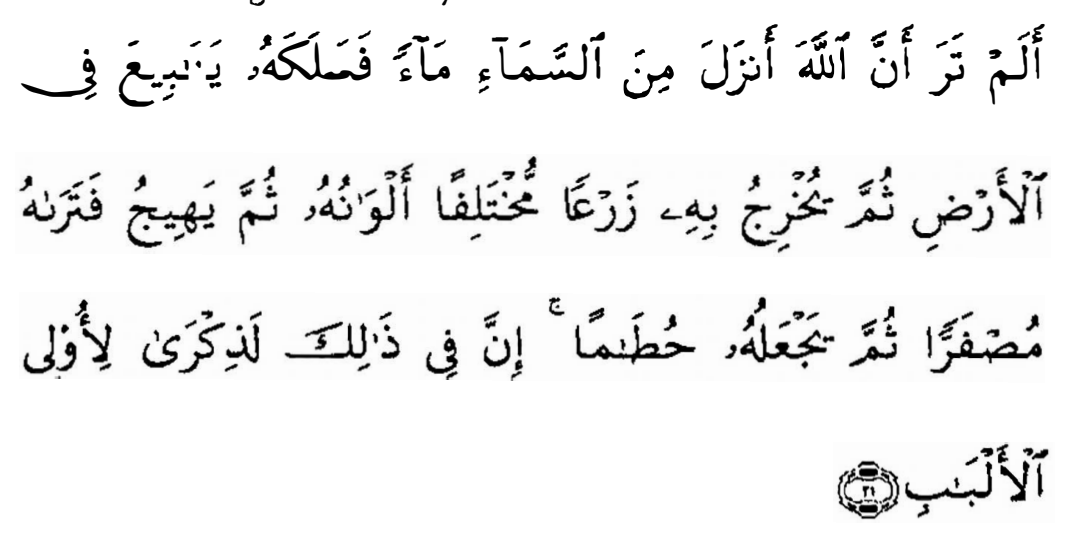

Ulul Albab, Vol. 10, No. 1, 2009 
Apakah kamu tidak memperhatikan, bahwa sesungguhnya Allah menurunkan air dari langit, maka diaturnya menjadi sumber-sumber air di bumi kemudian ditumbuhkanNya dengan air itu tanam-tanaman yang bermacam-macam warnanya, lalu menjadi kering lalu kamu melihatnya kekuning-kuningan, kemudian dijadikanNya hancur berderai-derai. Sesungguhnya pada yang demikian itu benar-benar terdapat pelajaran bagi orang-orang yang mempunyai akal (QS. az Zumar: 21)

Ilmu pengetahuan alam syahadat, sama seperti ayat-ayat al Quran, mendorong manusia agar lebih dekat kepada Allah, pencipta, pemilik dan pengatur alam jagat. Mempelajari alam jagad ciptaanNya, akan menjadi obat hati kita sama seperti pemahaman atas makna dan maksud ayat-ayat al Quran yang akan menambah kedekatan kita pada Allah. Obat ini tidak hanya berguna untuk penyakit-penyakit batin retapi juga untuk penyakit-penyakit dzahir seperti yang dijelaskan dalam hadist Rosululloh yang mulia,

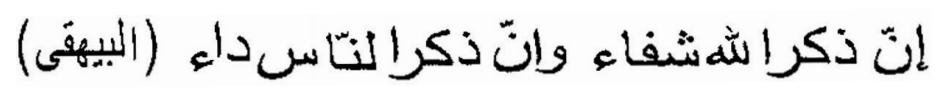

Menyebut-nyebut Allah adalah suatu penyembuhan dan menyebut-nyebut manusia adalah penyakic (maksudnya; penyakit akhlak) (HR. Al Baihaqi).

Maksud menyebut-nyebut Allah dalam hadits tersebut bukan hanya dzikir yang dilafazdkan tetapi juga mempelajari ciptaanNya yang berfungsi sebagai obat. Kiranya diperlukan kajian yang terus menerus untuk mengungkap semakin banyak lagi manfaat dari diciptakanya kelor ini bagi manusia, seperti yang dijelaskan dalam hadist Rasulullah yang mulia,

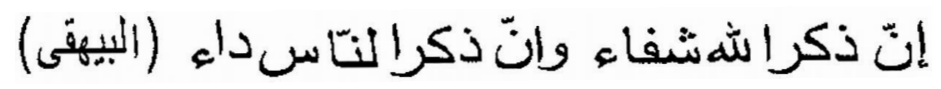

Apabila Allah menginginkan kebaikan bagi seseorang maka dia diberi pendalaman dalam ilmu agama. Sesungguhnya memperoleh ilmu hanya dengan belajar (HR. Bukhari). 


\section{Daftar Pustaka}

Chandra, A. 2001. Pemanfaatan Biji Kelor Dalam Pengolahan Limbah Cair Pabrik Tekstil. (Online). http://www.terranet.or.id/. Diakses 21 Oktober 2006.

Dwiriyanti. D. 2005. Pengolahan Lindi dengan biji Moringa oleivera.Lamk dan Membrane Mikrofiltrasi. Makalah Jurnal Kimia Lingkungan. Disampaikan pada Seminar Kimia Lingkungan VII di Surabaya.

Esti dan Sahar, H. 2002. Penjernihan Air Dengan Biji Kelor (Moringa oleivera.Lamk), (Online). http://www.ristek.go.id. Diakses $6 \mathrm{Mei}$ 2007.

Hammer., Mark. J and Hammer, Mark. J.Jr. 1996. Water and Wastewater .Technology, Third Edition. Prentice Hall International Edition.

Hasanah. U. 2008. Efektifitas Biji Kelor (Moringa oleivera.Lamk) sebagai Koagulan Limbah Cair Rumah Sakit. Studi Kasus di RSU dr Saiful Anwar Malang. Skripsi. Universitas Islam Negeri Malang.

Hidayat, Saleh. 2006. Pemberdayaan masyarakat bantaran Sungai Lematang dalam menurunkan kekeruhan air dengan biji kelor (Moringa oleivera.Lamk) sebagai upaya pengembangan proses penjernihan air. Disertasi. Program Pascasarjana Program Studi Pendidikan Biologi. Universitas Negeri Malang.

Inayati, E.S. 2006. Uji Efek Analgetik Ekstrak Etanol Daun Kelor (Moringa oleivera.Lamk) Pada Mencit Betina Dengan Metode Rangsang Kirnia, Skripsi, UMS Digital Library. (Online). /Top /S1-Final Projects/Fakultas Farmasi/K100-2006/jtptums-gdl-s1-2006enysayyida-2198. Diakses 6 Mei 2009.

Khoiroh, L.M. 2008. Efektifitas Koagulasi Ion Paraquat (1,1-Dimetil,4,4Bipiridilium) Menggunakan Biji Kelor (Moringa oleivera.Lamk). Skripsi. Universitas Islam Negeri Malang.

Logu, D. 2005. Moringa oleivera.Lamk exports. (Online). http:// murungaexports,ebigchina.com/. Diakses 23 Mei 2006. 
Nashiruddin, M. al Albani. Tt. Ringkasan Shahih Bukhori, Kitab Ilmu, Bab 14, Gema Insani Press (Hadits Web).

Wassil, J.A. 2001. Memahami Isi Kandungan al Quran. Jakarta: UI Press.

Winarno, FG. 2003. Berita KAI, Biji Kelor untuk Bersihkan Air Sungai, 7 April 2003, Unika Atma Jaya, Kemitraan Air Indonesia. (Online). http://www.inawater.com/news. Diakses 23 Mei 2006.

www.gardenorganic.org.uk/pdfs/international_programme/Moringa oleivera.Lamk.pdf, Moringa oleivera.Lamk A multy purpose tree, Diakses tanggal 26 Mei 2009

www.treesforlife.org/our-work/our-initiatives/Moringa oleivera.Lamk, How to grow Moringa oleivera.Lamk, Trees for life International. (Online). Diakses 26 Mei 2009.

Yulianti, E. 2007. Studi Interaksi Antara Biji Kelor (Moringa oleivera.Lamk) Dan Pestisida Paraquat (1,1'-Dimetil-4,4'bipiridilium Diklorida) Dan Phospat Dalam Medium Air. Lembaga Penelitian dan Pengembangan. UIN Malang.

Yulianti, E., Savitri, E.S, dan Dewi, D.C. 2006. Pemanfaatan Biji Kelor Sebagai Bioflokulan Logam Berat $\mathrm{Hg}, \mathrm{Pb}$ Dan Cr Pada Limbah Cair Industri Keramik Dinoyo Malang. Lembaga Penelitian dan Pengembangan. UIN Malang.

QS. al Qaaf: 50.

QS. al Fath: 48.

QS. al Imron: 190.

QS. an Nahl: 11.

Qs. asy Syu'ara: 7.

QS. az Zumar: 21. 